Penelitian

\title{
Evaluasi Tingkat Kejenuhan Amonium Sulfat pada Pemurnian Gama Imunoglobulin Anti-Aeromonas Hydrophila Poliklonal untuk Uji Imunohistokimia
}

\author{
(Evaluation Of Ammonium Sulphate Saturation Level In Polyclonal Hydrophila Hydrophila \\ Gama Immunoglobulin Purification For Immunohistochemical Testing) \\ Tanjung Penataseputro ${ }^{1,2^{*}}$, Dewi Ratih Agungpriyono ${ }^{3^{*}}$, \\ Ekowati Handharyani ${ }^{3}$, Bambang Widyo Prastowo ${ }^{1}$ \\ ${ }^{1}$ Loka Pemeriksaan Penyakit Ikan dan Lingkungan Serang \\ ${ }^{2}$ Mahasiswa Pascasarjana Ilmu Biomedis Hewan, Sekolah Pascasarjana, Institut Pertanian Bogor \\ 3Departemen Klinik, Reproduksi, dan Patologi, Fakultas Kedokteran Hewan, Institut Pertanian Bogor \\ *Penulis untuk korespondensi: tanjungpenataseputro@gmail.com; dewira@apps.ipb.ac.id \\ Diterima 2 Januari 2021, Disetujui 8 Juli 2021
}

\begin{abstract}
ABSTRAK
Prinsip interaksi antigen-antibodi menyebabkan antibodi banyak diproduksi untuk dimanfaatkan dalam mendeteksi penyakit dengan uji immunoassay. Antibodi yang diperoleh dari serum darah kelinci biasanya masih tercampur oleh berbagai macam protein darah, sehingga perlu dilakukan pemurnian. Pemurnian antibodi dari serum umumnya menggunakan ammonium sulfat (Suhito, 2016). Penelitian ini bertujuan untumemvariasikan tingkat kejenuhan ammonium sulfat untuk memberikan informasi yang optimal dalam presipitasi gama imunoglobulin (IgG). Hasil penelitian ini menyimpulkan bahwa imunisasi ulang (boosting) sangat baik untuk dilakukan dalam pembuatan antibodi dan antibodi dapat dimurnikan secara optimum menggunakan amonium sulfat dengan kejenuhan $35-42 \%$ untuk dilanjutkan proses dialisis. Antibodi yang dihasilkan mampu mendeteksi antigen dan toksin dari A. hydrophila dan dapat diaplikasikan pada uji imunohistokimia.
\end{abstract}

Kata kunci: Ammonium Sulfat, Presipitasi, Antibodi, Imunohistokimia

\begin{abstract}
Interaction antigen-antibody principle has been causing antibodies widely produced and used for detect disease by immunoassay. Antibody obtained from rabbit blood serum usually still mixed with various bloodproteins so that it needs to be purified. Antibody purification from serum generally uses ammonium sulfate (Suhito, 2016). This study varied the ammonium sulfate saturation level to provide optimal information in gamma immunoglobulins (IgG) precipitation. The results concluded that boosting immunization was very good in antibody production and it could be purified optimally by using $35-42 \%$ saturated ammonium sulfate and continued with dialysis. The antibody was able to detect $A$. hydrophila antigens and toxins and it can be applied in immunohistochemistry.
\end{abstract}

Keywords: Ammonium sulfate, precipitation, antibody, immunohistochemistry 


\section{PENDAHULUAN}

Antibodi merupakan komponen penting dari respon kekebalan spesifik (Adaptive/Acquired Immunity) karena adanya paparan antigen ke dalam tubuh. Interaksi antigen-antibodi menghasilkan ikatan affinitas tinggi seperti 'gembok dan anak kunci' (Day \& Schultz, 2014). Prinsip interaksi ini menyebabkan antibodi banyak diproduksi untuk dimanfaatkan dalam mendeteksi penyakit dengan uji immunoassay seperti ELISA, imunohistokimia, uji presipitasi agar gel bahkan dalam pembuatan kit imunokromatografi.

Jenis antibodi yang umum diproduksi ialah antibodi poliklonal karena pengembangannya lebih mudah dengan biaya rendah. Antibodi poliklonal umumnya diperoleh dari darah kelinci, kambing atau kuda melalui imunisasi dengan antigen. Antibodi yang diperoleh dari serum darah biasanya masih tercampur oleh berbagai macam protein darah sehingga perlu dilakukan pemurnian.

Pemurnian antibodi dari serum umumnya menggunakan ammonium sulfat karena sifatnya yang sangat larut, murah, dan memiliki tingkat pemurnian tertinggi serta tidak mengubah $\mathrm{pH}$ yang dapat mengakibatkan denaturasi protein (Suhito, 2016). Amanu et al., (2015a) menggunakan larutan ammonium sulfat $50 \%$ jenuh yang ditambahkan ke dalam serum. Alviyulita et al., (2014) melaporkan penggunaan kristal ammonium sulfat pada tingkat kejenuhan 60\% optimal untuk memisahkan enzim papain. Subangkit (2013) menggunakan larutan amonium sulfat $100 \%$ jenuh yang ditambahkan ke dalam serum sebanyak $40 \%$ dari volume serum.

Penelitian ini memvariasikan tingkat kejenuhan ammonium sulfat untuk memberikan informasi yang optimal dalam mengendapkan gama imunoglobulin ( $\lg G)$. Hasil pengendapan diukur konsentrasi lgG dan kemurnian serumnya dengan Multiskan Sky $\mu$ Drop dan secara visual. Hasil pengendapan IgG yang paling optimal dilakukan dialisis dan diaplikasikan pada uji imunohistokimia.

\section{BAHAN DAN METODE}

Alat dan Bahan

\section{Antibodi Anti A. hydrophila}

Antibodi anti A. hydrophila diproduksi pada seekor kelinci jantan lokal berumur 7-12 bulan dengan berat badan 1,8-2,5 kg yang diimunisasi dengan antigen somatik $\mathrm{O}$ bakteri Aeromonas hydrophila sebanyak $0,5 \mathrm{ml}$ dengan kepadatan
$1.2 \times 10^{9} \mathrm{cfu} \mathrm{ml}^{-1}$ melalui vena aurikularis seperti yang dilakukan Amanu et al., (2015b) tanpa menggunakan adjuvant. Imunisasi ulang dilakukan seminggu kemudian sebanyak 1,5 kali dosis awal. Imunisasi ulang (boosting) dilakukan sebanyak dua kali. Penggunaan kelinci dalam penelitian ini telah mendapat persetujuan dari Komisi Etik Hewan IPB dengan nomor 175-2020 IPB. Pengambilan darah sebanyak $1 \%$ dari volume total darah melalui vena aurikularis medial dilakukan setiap minggu atau sebanyak 4 kali untuk pengukuran titer antibodi sebelum injeksi antigen.

Pengukuran titer antibodi dilakukan dengan pengenceran serum dengan larutan Phosphate Buffered Saline (PBS) (1:1) dan dilakukan serial pengenceran dua kali lipat, sehingga pengenceran serum adalah 1:2, 1:4, 1:8, 1:16, 1:32, 1:64, 1:128, 1:256, 1:512, 1:1024 dan 1:2048. Suspensi $A$. hydrophila $\left(1,2 \times 10^{9}\right.$ $\mathrm{CFU} / \mathrm{ml}$ ) tidak aktif ditambahkan ke masing-masing sumur dan kemudian ditutup dengan plastik film. Inkubasi dilakukan pada suhu kamar selama 16-18 jam. Titik aglutinasi akhir ditetapkan sebagai pengenceran serum terakhir di mana aglutinasi terlihat. Titer aglutinasi antibodi dinyatakan dari kebalikan dilusi serum tertinggi yang menunjukkan aglutinasi. Titer antibodi diekspresikan dengan menghitung nilai Geometric Mean Titre (GMT) sebagai Log2 (X +10) (Biller-Takahashi, 2014; Safrullah, 2016). Pengukuran konsentrasi IgG dan kemurnian serum dilakukan menggunakan Multiskan Sky $\mu$ Drop dengan cara memasukan $2 \mu \mathrm{l}$ serum pada mikroplate kaca yang dimasukan pada alat dan dibaca dengan panjang gelombang 28onm. Pemanenan serum dilakukan dengan pengambilan darah total pada kelinci. Darah yang telah diperoleh disimpan pada suhu ruang selama 2 jam dan dilanjutkan penyimpanan pada suhu $4^{\circ} \mathrm{C}$ selama satu malam (Subangkit, 2013).

\section{Presipitasi dan Dialisis}

Darah disentrifugasi pada $10.000 \times$ g selama 15 menit untuk memisahkan serum dengan darah. Serum disentrifugasi kembali pada $10.000 \times g$ selama 10 menit (Subangkit, 2013). Presipitasi dilakukan dengan dua cara yaitu penambahan kristal amonium sulfat dalam serum dengan tingkat kejenuhan $25 \%$, 35\%, 43\%, 50\%, 65\%, 78\%, dan $100 \%$ dan penambahan larutan ammonium sulfat jenuh $(\mathrm{pH}$ 7.8-8.0) ke dalam serum dengan tingkat kejenuhan $25 \%, 33 \%, 38 \%, 40 \%, 42 \%, 50 \%, 67 \%, 75 \%, 80 \%$ dan $83 \%$. Presipitasi dilakukan pada suhu ruang. Serum kemudian disentifugasi pada 6000 gram selama 
30 menit. Pelet yang terbentuk diresuspensikan dengan PBS ( $\mathrm{pH} 7.2$ ) hingga volume awal (Amanu et al., 2015a). Konsentrasi IgG dan kemurnian serum diukur menggunakan alat Multiskan Sky $\mu$ Drop pada panjang gelombang $280 \mathrm{~nm}$ (Noble \& Bailey, 2009; Hirte, 2016). Hasil presipitasi optimum dilanjutkan proses dialisis menggunakan membrane nitroselulosa selektif dan larutan PBS ( $\mathrm{pH}$ 8.0) selama 2 malam pada suhu $4^{\circ} \mathrm{C}$ dan dilakukan pergantian PBS setiap 12 jam sekali. Tahapan terakhir pemurnian dilakukan dengan menggunakan melon gel lgG purification Kit dan diukur kembali konsentrasi IgG dan kemurnian serumnya (Evan, 2017).

\section{Imunohistokimia}

Anti-aeromonas IgG yang diperoleh diaplikasikan dalam pengujian imunohistokimia pada jaringan otot ikan lele (Clarias sp) yang terinfeksi bakteri Aeromonas hydrophila dan Edwardsiella tarda. Pengujian imunohistokimia mengacu pada Kristianingrum et al., (2018) dengan modifikasi. Jaringan otot dipotong setebal $4-5 \mu \mathrm{m}$ dan diletakkan pada gelas objek. Deparafinasi dilakukan dengan meletakkan slide jaringan pada hot plate $62^{\circ} \mathrm{C}$ selama 1 menit. Slide jaringan rendam dalam xylene sebanyak 3 kali dengan waktu masing-masing selama 5 menit.

Rehidrasi dilakukan menggunakan etanol bertingkat mulai dari etanol absolut, etanol 95\%, etanol $80 \%$, dan etanol $70 \%$ masing-masing selama 1 menit. Slide jaringan dibilas dengan akuades. Pencucian dengan PBS dan $0.05 \%$ tween 20 sebanyak 2 kali masing-masing selama 5 menit. Blocking endogenous peroxidase menggunakan $3 \% \mathrm{H}_{2} \mathrm{O}_{2}$ dalam $\mathrm{PBS}$ selama 10 menit dan dilanjutkan pencucian dengan PBS dan $0.05 \%$ tween 20 sebanyak 2 kali masing-masing selama 5 menit.

Slide jaringan dilanjutkan dengan blocking normal serum selama 10 menit dan dilanjutkan dengan inkubasi antibodi primer (poliklonal) dengan pengenceran $64 x$ terhadap $A$. hydrophila selama 24 jam (overnight) pada suhu $4^{\circ} \mathrm{C}$, selanjutnya dicuci dengan PBS dan $0.05 \%$ tween 20 sebanyak 2 kali masing-masing selama 5 menit. Inkubasi dilakukan dengan IgG anti-rabbit yang telah terkonjugasi dengan Horse Radish Peroxidase (HRP) selama 30 menit dan dicuci PBS sebanyak 3 kali masing-masing selama 5 menit. Pewarnaan kromogen DAB (3-3, diaminobenzidine) dilakukan hingga intensitas warna yang diinginkan muncul kemudian dicuci dengan akuades dan dilanjutkan counterstain dengan Mayer's Hematoxylin selama 1 menit. Slide direndam dalam air mengalir selama 6 menit dan dilakukan dehidrasi, clearing dan ditutup dengan cover glass.

\section{Analisis Data}

Nilai konsentrasi IgG dan kemurnian serum dianalisa dengan anova single factor dan dilakukan uji Beda Nyata Terkecil (BNT) untuk melihat perbedaan antar perlakuan. Data imunohistokimia diinterpretasikan secara deskriptif.

\section{HASIL}

Hasil imunisasi pada kelinci dengan antigen somatik O (AgO) A. hydrophila menunjukan peningkatan titer antibodi yang signifikan terjadi pada minggu ke 3 setelah dilakukan imunisasi ulang (boosting) pertama (Tabel 1). Nilai GMT titer antibodi pada minggu ke 3 sebesar 303,44 dengan titik aglutinasi pada $2^{8}$, konsentrasi $\lg \mathrm{G} 36,33 \pm 0,26 \mathrm{mg}$ $\mathrm{ml}^{-1}$ dan kemurnian serum $0,74 \pm 0,06$. Boosting kedua tidak memberikan pengaruh yang signifikan terhadap nilai titer antibodi namun menunjukan kemurnian serum yang semakin rendah sehingga dilakukan panen serum total. Hasil ini menunjukan pentingnya dilakukan boosting setidaknya 1 kali seminggu setelah imunisasi. Serum yang diperoleh pada penelitian ini memiliki titer antibodi sebesar 361,04 dengan titik aglutinasi pada $2^{8}$, konsentrasi IgG $37,09 \pm 1,5 \mathrm{mg} \mathrm{ml}^{-1}$ dan kemurnian serum $0,79 \pm 0,02$.

Serum dimurnikan menggunakan ammonium sulfat dan dilanjutkan dengan dialisis pada membran semipermeable. (Amanu et al. 2015a). Secara visual presipitasi lgG menggunakan serbuk ammonium

Tabel 1 Titer antibodi, konsentrasi IgG dan kemurnian serum setelah imunisasi (rerata $\pm \mathrm{sd}$ )*

\begin{tabular}{|c|c|c|c|c|}
\hline \multirow{2}{*}{ Minggu } & \multicolumn{2}{|c|}{ Titer Antibodi } & \multirow{2}{*}{ Konsentrasi lgG $\left(\mathrm{mg} \mathrm{ml}^{-1}\right)$} & \multirow{2}{*}{ Kemurnian } \\
\hline & AMT & GMT & & \\
\hline 1 & 0 & 0 & $33,35 \pm 0,37^{a}$ & $0,71 \pm 0,01^{2}$ \\
\hline 2 & 5,75 & 52,82 & $33,95 \pm 0,29^{a}$ & $0,73 \pm 0,02^{z}$ \\
\hline 3 & 8,25 & 303,44 & $36,33 \pm 0,26^{b}$ & $0,74 \pm 0,06^{2}$ \\
\hline 4 & 8,5 & 361,04 & $37,09 \pm 1,50^{\mathrm{b}}$ & $0,79 \pm 0,02^{y}$ \\
\hline
\end{tabular}

*Perbedaan yang signifikan ditunjukkan dengan huruf yang berbeda $(p<0,5)$ dalam kolom yang sama 
sulfat optimum pada kejenuhan 25-35\% (Gambar 1A) sedangkan penggunaan larutan ammonium sulfat jenuh optimum pada kejenuhan 25-42\% (Gambar 1B). Warna krem bening merupakan indikasi IgG berhasil dipisahkan protein lain didalam serum dan sisa-sisa sel darah yang lisis. Tabel 2 dan 3 secara kualitatif menunjukan bahwa semakin jenuh ammonium sulfat yang digunakan konsentrasi IgG akan semakin tinggi namun kemurnian akan semakin rendah. Kemurnian serum yang baik ditunjukan pada penggunaan larutan ammonium sulfat 33-50\% jenuh dan serbuk ammonium sulfat pada kejenuhan $35 \%$. Presipitasi IgG menggunakan serbuk ammonium sulfat optimum dilakukan pada kejenuhan 35\% dengan konsentrasi IgG yang diperoleh sebesar $16,82 \pm 1,39 \mathrm{mg} \mathrm{ml}^{-1}$ dan kemurnian serum 0,60 $\pm 0,01$. Penggunaan larutan ammonium sulfat jenuh optimum dilakukan pada kejenuhan 38-42\% dengan konsentrasi Ig $G$ yang diperoleh berkisar 16,14 $\pm 1,9-$ $17,01 \pm 0,94 \mathrm{mg} \mathrm{ml}^{-1}$ dan kemurnian serum 0,59 $\pm 0,01$ (tabel 6). Hasil dialisis menunjukan konsentrasi lgG yang lebih besar dengan kemurnian serum yang lebih baik jika dibandingkan dengan IgG komersial secara signifikan (Tabel 4).

Hasil pemurnian akhir menggunakan melon gel $\lg G$ purification kit diperoleh konsentrasi lgG 9,96 \pm $0,31 \mathrm{mg} \mathrm{ml}^{-1}$ dan kemurnian serum 0,58 $\pm 0,00$ sehingga kadar IgG yang dibutuhkan untuk dapat mengaglutinasi bakteri sejumlah $50 \mu$ lari $1,2 \times$ $10^{9} \mathrm{cfu} \mathrm{ml}^{-1}$ dihitung dengan cara mengkalikan volume serum dengan nilai konsentrasi IgG dan membaginya dengan nilai GMT $\left(50 \mu \mathrm{l} \times 9,96 \mathrm{mg} \mathrm{ml}^{-1} /\right.$ 21,63 ) sehingga diperoleh nilai $23,01 \mu g$. Antibodi poliklonal yang dihasilkan dalam penelitian ini mampu mengaglutinasi $1,3 \times 10^{6}$ bakteri $A$. hydrophila per $1 \mu g$ antibodi.

Antibodi diaplikasikan untuk uji imunohistokimia pada jaringan otot ikan lele (Clarias spp.) dengan gejala ulserasi pada tubuh yang terkonfirmasi bakteri Aeromonas hydrophila secara PCR dan histopatologi (Gambar 2a). Koleksi jaringan otot terkonfirmasi Edwardsiella tarda digunakan sebagai kontrol negatif. Hasil uji imunohistokimia (Gambar 2b) menunjukan adanya ikatan antibodi dengan antigen bakteri dan toksin bakteri pada jaringan otot yang ditandai dengan adanya warna coklat gelap. Pada kontrol negatif (Gambar 2c) terlihat bakteri Edwardsiella tarda yang terwarnai hematoxylin tanpa adanya warna kecoklatan. Hal ini sesuai dengan Kristianingrum et al., (2018) yang menyatakan adanya ikatan antigen bakteri dengan antibodi ditunjukan adanya warna kecoklatan pada organ yang merupakan reaksi ikatan antigen dan antibodi dengan 3-3, diaminobenzidine (DAB).

\section{PEMBAHASAN}

Penyediaan antibodi pada individu dihasilkan melalui proses rekombinasi somatik pada segmen gen germline. Diversifikasi lebih lanjut merupakan hasil dari proses mutasi somatik pada region variable. Mutasi somatik dan seleksi memungkinkan pematangan afinitas antibodi untuk mencapai diversifikasi antibodi (Delves et al., 2017). Antigen yang disuntikan ditangkap oleh sel dendrit dan memecah molekul-molekul antigen. Sel limfosit $\mathrm{T}$ akan mengenali
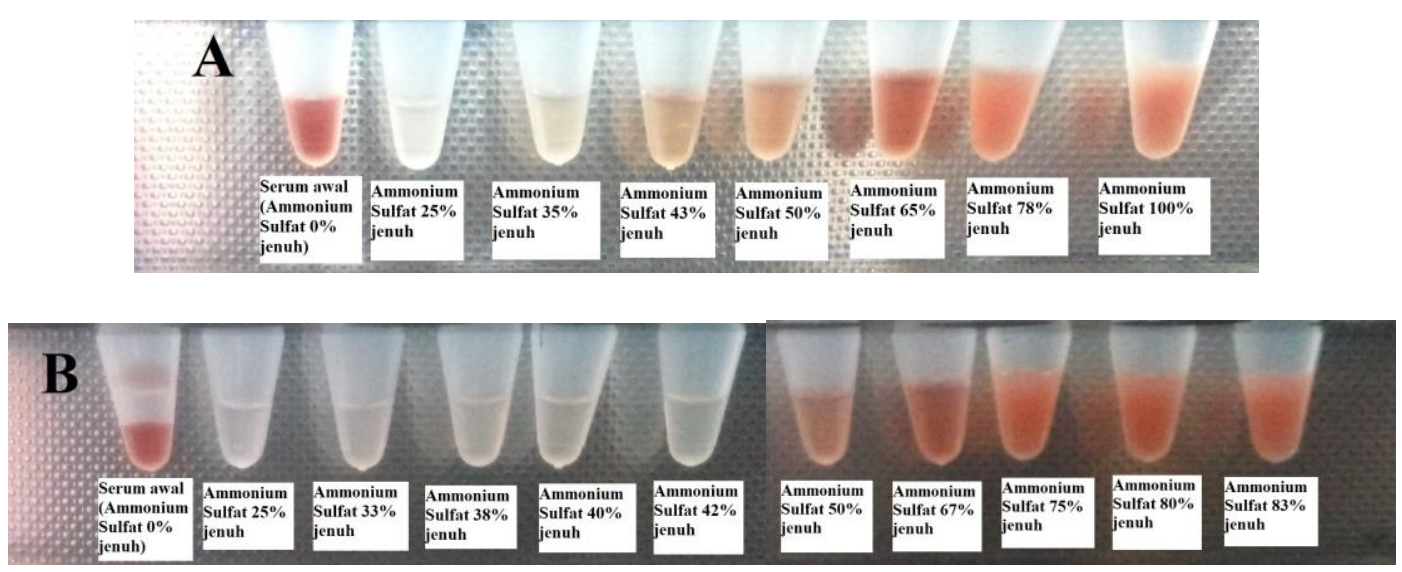

Gambar 1 Hasil presipitasi secara visual pada tingkat kejenuhan yang berbeda. Keterangan: A. Presipitasi dengan serbuk ammonium sulfat; $B$. presipitasi dengan larutan ammonium sulfat 
Tabel 2 Hasil presipitasi dengan serbuk ammonium sulfat pada tingkat kejenuhan yang berbeda (rerata $\pm \mathrm{sd})^{*}$

\begin{tabular}{cccc}
\hline Kejenuhan (\%) & Molaritas $(M)$ & Konsentrasi lgG $\left(\mathrm{mg} \mathrm{ml}^{-1}\right)$ & Kemurnian \\
\hline Serum & - & $37,09 \pm 1,50^{\mathrm{b}}$ & $0,79 \pm 0,02^{\mathrm{y}}$ \\
25 & 1,1 & $6,63 \pm 0,15^{\mathrm{c}}$ & $0,62 \pm 0,00^{\mathrm{x}}$ \\
35 & 1,6 & $16,82 \pm 1,39^{\mathrm{e}}$ & $0,60 \pm 0,01^{\mathrm{x}}$ \\
43 & 2,0 & $24,13 \pm 1,51^{\mathrm{f}}$ & $0,62 \pm 0,01^{\mathrm{x}}$ \\
50 & 2,4 & $26,09 \pm 6,63^{\mathrm{f}}$ & $0,68 \pm 0,05^{\mathrm{w}}$ \\
65 & 3,3 & $30,55 \pm 0,83^{\mathrm{g}}$ & $0,64 \pm 0,01^{\mathrm{x}}$ \\
78 & 4,2 & $27,61 \pm 0,67^{\mathrm{f}}$ & $0,75 \pm 0,08^{\mathrm{y}}$ \\
100 & 4,2 & $21,39 \pm 2,73^{\mathrm{f}}$ & $0,89 \pm 0,02^{\mathrm{u}}$ \\
\hline
\end{tabular}

*Perbedaan yang signifikan ditunjukkan dengan huruf yang berbeda $(\mathrm{p}<0,5)$ dalam kolom yang sama

molekul-molekul antigen dengan bantuan $\mathrm{CD}_{4}+$ (pada sisi sel T) dan Major Histocompatibility Complex (MHC) II serta mensintesis sitokin (interleukin (IL)-4, IL-5, IL-9 dan IL-13) untuk membantu Sel limfosit $\mathrm{B}$ berdiferensiasi menjadi sel plasma yang mampu mensekresi antibodi pada sistem kekebalan humoral (Day \& Schultz, 2014). Hasil penelitian ini menunjukan pentingnya dilakukan imunisasi ulang (boosting) sesuai dengan yang dilaporkan Subangkit (2013) bahwa imunisasi meningkatkan titer sebesar 2,45 kali dan imunisasi ulang sebesar 33 kali dari titer awal. Antibodi dapat dipanen setelah menunjukkan titer antibodi sebesar 1:64 (Amanu et al., 2015b). Hasil pemanenan antibodi menunjukan konsentrasi IgG yang tinggi dengan kemurnian serum yang rendah. Pada umumnya makin murni antibodi maka makin spesifik antibodi tersebut, tetapi antibodi yang murni tidak relatif memiliki kadar konsentrasi yang tinggi (Fusvita, 2016). Kemurnian protein serum dapat diukur dengan pendekatan rasio $\lambda_{260} / \lambda_{280}$. Rasio $\lambda_{260} / \lambda_{280}$ untuk protein yang umum adalah 0,5-0,55 (Béguin, 2018).

Pemisahan IgG dengan protein lain dalam serum dilakukan dengan metode presipitasi menggunakan ammonium sulfat dilanjutkan dengan dialisis pada membran semipermeabel (Amanu et al., 2015a). Amonium sulfat digunakan untuk memecah ikatan Ig $\mathrm{C}$ dengan $\mathrm{H}_{2} \mathrm{O}$ di dalam serum dengan proses salting out sehingga protein akan mengendap. Salting out terjadi akibat kompetisi antara ion dari garam amonium dan molekul protein dalam berinteraksi dengan molekul air. Tingginya kadar ion, menyebabkan molekul protein berinteraksi dengan molekul protein lainnya sehingga membentuk endapan dan akan mengendap jika disentrifugasi (Sinaga et al., 2014). Kejenuhan ammonium sulfat di dalam serum menentukan nilai molaritas yang akan mempengaruhi pengendapan protein serum jika disentrifugasi. Menurut Evan (2017), IgG akan mulai mengendap pada molaritas $1,5 \mathrm{M}$ dan protein lainnya mengendap pada molaritas $2 \mathrm{M}$. Presipitasi IgG menggunakan serbuk ammonium sulfat optimum dilakukan pada kejenuhan $35 \%$ dan penggunaan larutan ammonium sulfat jenuh optimum pada kejenuhan $38-42 \%$ dimana rasio kemurnian serum mencapai 0,59-0,60. Kemurnian serum dapat diukur dengan pendekatan rasio protein dalam serum pada $\lambda_{260} / \lambda_{280}$ dengan nilai 0,5-0,55 (Béguin, 2018). Berdasarkan NanoPhotometer dan DS-11 Series Spectrophotometer Technical Note, protein yang telah dimurnikan memiliki rasio $\lambda 260 / \lambda 280$ sekitar 0,57 dan 0,6 . Rasio yang lebih tinggi mengindikasikan adanya kontaminasi pada protein yang diisolasi.

Dialisis membran semipermeabel dilakukan untuk membersihkan sisa ammonium sulfat yang masih tertinggal di dalam larutan antibodi dengan prinsip osmosis (Herlina et al., 2019). Sisa ammonium sulfat dan kotoran lainnya akan keluar dari dalam membran dialisa menuju larutan PBS dan IgG akan tertahan karena ukuran pori-pori membran dialisa yang lebih kecil dari ukuran IgG. Saat terjadi Molaritas equlibrium penggantian larutan PBS harus dilakukan karena proses osmosis sudah tidak terjadi. Proses dialisis akan menyebabkan menurunnya nilai titer antibodi dan konsentrasi IgG namun meningkatkan kemurnian serum. 
192 | Penataseputro et al.

Tabel 3 Hasil presipitasi dengan larutan ammonium sulfat jenuh pada tingkat kejenuhan yang berbeda $(\text { rerata } \pm \mathrm{sd})^{*}$

\begin{tabular}{cccc}
\hline Kejenuhan (\%) & Molaritas $(M)$ & Konsentrasi lgG $\left(\mathrm{mg} \mathrm{ml}^{-1}\right)$ & Kemurnian \\
\hline Serum & - & $37,09 \pm 1,50^{\mathrm{b}}$ & $0,79 \pm 0,02^{\mathrm{y}}$ \\
25 & 1,20 & $5,28 \pm 4,53^{\mathrm{c}}$ & $0,68 \pm 0,06^{\mathrm{w}}$ \\
33 & 1,60 & $13,02 \pm 2,11^{\mathrm{d}}$ & $0,60 \pm 0,01^{\mathrm{x}}$ \\
38 & 1,80 & $16,14 \pm 1,9^{\mathrm{e}}$ & $0,59 \pm 0,01^{\mathrm{x}}$ \\
40 & 1,92 & $16,50 \pm 0,81^{\mathrm{e}}$ & $0,59 \pm 0,01^{\mathrm{x}}$ \\
42 & 2,00 & $17,01 \pm 0,94^{\mathrm{e}}$ & $0,59 \pm 0,00^{\mathrm{x}}$ \\
50 & 2,08 & $21,73 \pm 3,71^{\mathrm{f}}$ & $0,60 \pm 0,02^{\mathrm{x}}$ \\
67 & 2,77 & $30,11 \pm 1,26^{\mathrm{g}}$ & $0,64 \pm 0,02^{\mathrm{x}}$ \\
75 & 3,12 & $23,95 \pm 0,3^{\mathrm{f}}$ & $0,79 \pm 0,01^{\mathrm{y}}$ \\
80 & 3,33 & $25,26 \pm 0,5^{\mathrm{f}}$ & $0,84 \pm 0,01^{v}$ \\
83 & 3,47 & $25,05 \pm 0,2^{\mathrm{f}}$ & $0,83 \pm 0,01^{v}$ \\
\hline
\end{tabular}

*Perbedaan yang signifikan ditunjukkan dengan huruf yang berbeda $(p<0,5)$ dalam kolom yang sama

Tabel 4 Konsentrasi IgG, kemurnian serum dan titer antibodi pada tahapan pemurnian (rerata \pm sd) ${ }^{*}$

\begin{tabular}{lcccc}
\hline \multirow{2}{*}{ Fraksi } & Konsentrasi $\operatorname{lgG}\left(\mathrm{mg} \mathrm{m}^{-1}\right)$ & Kemurnian & \multicolumn{2}{c}{ Titer Antibodi } \\
\cline { 4 - 5 } & & & AMT & GMT \\
\hline Serum & $37,09 \pm 1,50^{\mathrm{b}}$ & $0,79 \pm 0,02^{\mathrm{y}}$ & 8,5 & 361,04 \\
Dialisis & $11,45 \pm 0,44^{\mathrm{h}}$ & $0,59 \pm 0,00^{\mathrm{t}}$ & 5,25 & 37,05 \\
Purification Kit & $9,96 \pm 0,31^{\mathrm{i}}$ & $0,58 \pm 0,00^{\mathrm{s}}$ & 4,5 & 21,63 \\
IgG komersial & $8,04 \pm 0,39^{\mathrm{j}}$ & $0,68 \pm 0,00^{\mathrm{r}}$ & - & - \\
\hline
\end{tabular}

*Perbedaan yang signifikan ditunjukkan dengan huruf yang berbeda $(p<0,5)$ dalam kolom yang sama

Bakteri A. hydrophila termasuk dalam bakteri Gram negatif berbentuk batang pendek berukuran $0,8-1,0 \mu \mathrm{m}$ yang dapat menginfeksi berbagai jenis ikan (Hardi \& Pebrianto, 2012; Kusdarwati et al., 2017). Gambar 2b memperlihatkan morfologi $A$. hydrophila yang berbentuk batang dan terwarnai coklat gelap hal ini dikarenakan terserapnya warna DAB dan hematoxylin. Pada kontrol negatif bakteri hanya menyerap warna hematoxylin karena tidak adanya ikatan langsung antara bakteri dengan warna DAB.

Warna coklat gelap yang ditunjukan panah merah pada gambar $2 \mathrm{~b}$ bukanlah ikatan antara antibodi dengan bakteri melainkan ikatan antara antibodi toksin dari bakteri yang telah menginfiltrasi ke dalam jaringan sel. Penulis menduga bahwa antibodi yang dibuat tidak hanya membentuk kesesuaian dengan epitop dari antigen $A$. hydrophila namun juga membentuk kesesuaian dengan toksin yang dihasilkan A. hydrophila, sehingga toksin yangterdapat pada jaringan otot juga terikat oleh antibodi yang digunakan pada uji imunohistokimia ini. Dengan demikian antibodi yang digunakan dalam penelitian ini mampu mendeteksi antigen dari $A$. hydrophila dan toksin yang dihasilkannya. 

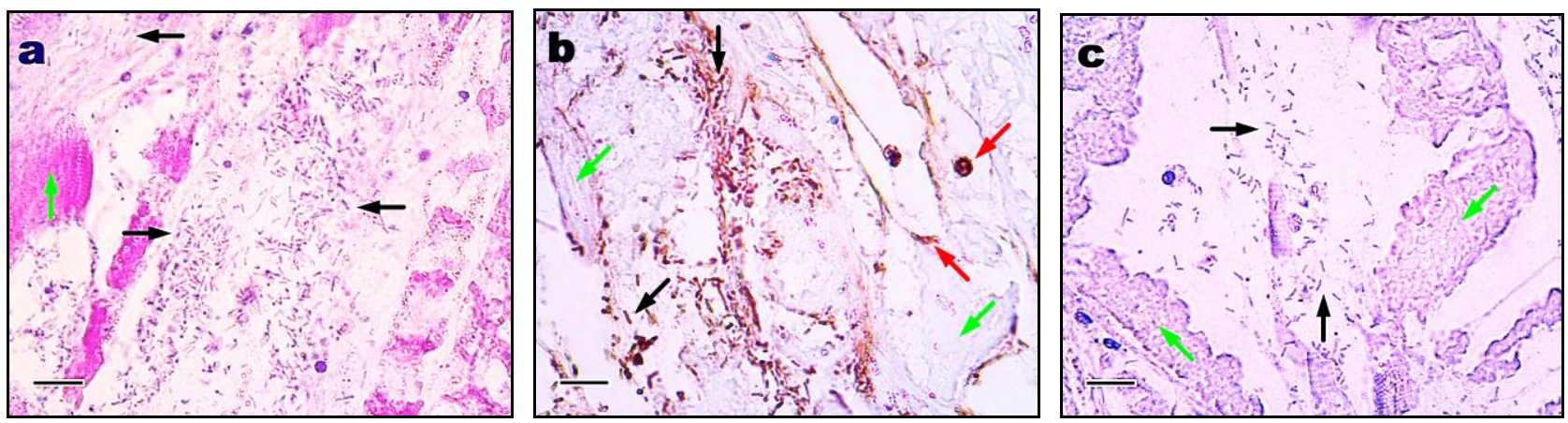

Gambar 2 Histopatologi otot ikan lele terinfeksi A. hydrophila (a dan b) dan Edwardiwlla tarda (c) memperlihatkan bakteri (panah hitam) berbentuk batang dengan toksin (panah merah) pada jaringan otot (panah hijau) yang mengalami nekrosis. Bar $=10 \mu \mathrm{m}$. Keterangan; A. HematoksilinEosin; B. Imunohistokimia positif bakteri A. hydrophila; C. Imunohistokimia kontrol negatif

Aeromonas hydrophila menghasilkan dua jenis toksin yaitu aerolysin dan hemolysin (Yousr et al., 2007). Aerolysin merupakan protein hidrofilik bersifat hemolitik dan sitolitik yang diproduksi oleh beberapa strain A. hydrophila. Aerolysin mengikat reseptor glikoprotein spesifik pada permukaan sel eukariot sebelum masuk ke dalam lapisan lemak dan membentuk lubang. Aerolysin menyebabkan lubang dan masuk ke dalam membran bakteri sebagai suatu preprotoksin yang mengandung peptida. Racun tersebut dapat menyerang sel-sel epitel dan menyebabkan gastroenteristis (Lukistyowati \& Kurniasih, 2012).

Penelitian ini menyimpulkan bahwa dalam pembuatan antibodi, imunisasi ulang (boosting) sangat baik untuk dilakukan dan antibodi dapat dimurnikan secara optimum dengan menggunakan ammonium sulfat pada kejenuhan $35-42 \%$ dan dilanjutkan proses dialisis. Antibodi yang dihasilkan dari penelitian ini mampu mendeteksi antigen dan toksin A. hydrophila pada uji imunohistokimia.

\section{UCAPAN TERIMA KASIH}

Ucapan terima kasih penulis sampaikan kepada Kementerian Kelautan dan Perikanan atas dukungan dana penelitian melalui Pusat Pendidikan Kelautan dan Perikanan, Badan Riset dan Sumber Daya Manusia Kelautan dan Perikanan, serta Loka Pemeriksaan Penyakit Ikan dan Lingkungan Serang yang telah memfasilitasi pelaksanaan penelitian ini.

"Penulis menyatakan tidak ada konflik kepentingan dengan pihak- pihak yang terkait dalam penelitian ini".

\section{DAFTAR PUSTAKA}

Alviyulita M, Hasibuan PRM, Hanum F. 2014. Pengaruh penambahan ammonium sulftat (NH4)2SO4 dan waktu perendaman buffer fosfat terhadap perolehan Crude Papain dari daun pepaya (Carica Papaya, L). Jurnal Teknik Kimia USU 3(3):8-12.

Amanu S, Rifai AB, Yulianah L, Dwiwahyu P. 2015 a. Evaluation of coaglutination test kit for red sea bream iridovirus. Journal of Agricultural Science and Technology B 5:437-440.

Amanu S, Untari T, Wibowo MH, Artanto S. 2015b. Pengembangan deteksi Aeromonas hydrophila pada ikan nila (Oreochromis niloticus) dengan metoda agar gel presipitasi di Yogyakarta. Jurnal Sain Veteriner 33(2):216-221.

Béguin, Pierre. 2018. Re: What are the best $260 / 280$ $\mathrm{nm}$ absorption ratios for high purity protein antigen?. Retrieved from: https://www.researchgate. net/post/What_are_the_best_260_280_nm_abso rption_ratios_for_high_purity_protein_antigen $/ 5$ abb599deeae391d041816c2/citation/download.

Download: Desember 29, 2020.

Biller-Takahashi JD, Montassier HJ, Takahashi LS, Urbinati EC. 2014. Proposed method for agglutinating antibody titer analysis and its use as indicator of acquired immunity in Pacu, Piaractus Mesopotamicus. Braz J Biol 74(1):238-242.

Day JM, Schultz DR. 2014. Veterinary Immunology Principles and Practice. $2^{\text {nd }}$ ed. CRC Press. p69-104.

Delves JP, Martin J, Burton RD, Roitt MI. 2017. Roitt's Essential Immunology. $13^{\text {th }}$ ed. Wiley Blacwell Press. p69-96. 
Evan Y. 2017. Pengembangan uji cepat metode koaglutinasi untuk mendeteksi antigen bakteri Vibrio parahaemolyticus penyebab penyakit vibriosis pada udang vaname. Tesis S2. Sekolah Pascasarjana, Intitut Pertanian Bogor. Bogor.

Fusvita A, Maryam R, Pribadi ES. 2016. Karakterisasi antibodi poliklonal terhadap aflatoksin M1. Jurnal Sain Veteriner 34(1):9-15.

Hardi EH, Pebrianto CB. 2012. Isolasi dan uji postulat koch Aeromonas sp. dan Pseudomonas sp. pada ikan nila (Oreochromis niloticus) di sentra budidaya loa kulu kabupaten kutai kartanegara. Jurnal Ilmu Perikanan Tropis 16(2):35-39.

Herlina N, Setiyono A, Juniantito V, Said S. 2019. Induksi dan purifikasi antibodi anti-Coxiella burnetii untuk deteksi post mortem Q fever pada ruminansia. Acta Veterinaria Indonesiana 7(1):1-10.

Hirte R. 2016. Measuring protein concentration in cell lysates by direct UV280 absorbance in the nanpphotometer ${ }^{\circledR}$ P330. Implen $\mathrm{GmbH}$ Application Note 1-6. https://www.implen.de/ scientific/measuring-protein-concentration-in-celllysates-by-direct-uv280-absorban ce-in-thenanophotometer-p330/. Download: Desember 29, 2020. .

Kristianingrum YP, Widyarini S, Kurniasih, Sutrisno B, Tabbu CR, Sugiyono. 2018. Pengembangan imunnodiagnostik untuk infeksi Aeromonas hydrophila pada ikan. Jurnal Sain Veteriner 36(1):86-87.

Kusdarwati R, Kismiyati, Sudarno, Kurniawan H, Prayogi YT. 2017. Isolation and identification of
Aeromonas hydrophila and Saprolegnia sp. on catfish (Clarias gariepinus) in floating cages in bozem moro krembangan surabaya. IOP coference series: earth and environmental science 55012038.

Lukistyowati I, Kurniasih. 2012. Pelacakan gen aerolysin dari Aeromonas hydropila pada ikan mas yang diberi pakan ekstrak bawang putih. Jurnal Veteriner 13(1):43-50.

Noble JE, Bailey JA. 2009. Quantitation of Protein. Methods Enzymol. 463:73-95.

Safrullah. 2016. Pembuatan Prototipe Kit Imunokromatografi untuk Mendeteksi Antigen Edwardsiella tarda. Tesis S2. Sekolah Pascasarjana, Institut Pertanian Bogor. Bogor. p45-46.

Sinaga M, Nugroho TT, Dahliaty A. 2014. Pemekatan enzim selulase Penicillium sp. LBKURCC20 dengan pengendapan ammonium sulfat $80 \%$ jenuh. Jurnal FMIPA 283-288.

Subangkit M. 2013. Kajian Diagnostik Patologi Penyakit Marek Menggunakan Metode Imunohistokimia. Tesis S2. Sekolah Pascasarjana, Institut Pertanian Bogor. Bogor. p24-39.

Suhito IR. 2016. Ekstraksi, Purifikasi, dan Karakterisasi Alkalin Protease dari Limbah Buah Naga Merah (Hylocereus polyrhizus). Skripsi S1. Universitas Surabaya. Surabaya. p12-37.

Yousr AH, Napis S, Rusul GRA, Son R. 2007. Detection of aerolysin and hemolysin genes in Aeromonas spp. isolated from environmental and shellfish sources by Polymerase Chain Reaction. ASEAN Food Journal 14(2):115-122. 